\title{
Industrial Growth and Environmental Resource toward the Tax Potential: A Case Study in South Sulawesi Province
}

\author{
Muh. RUM ${ }^{1}$, Anisa KUSUMAWARDANI ${ }^{2}$
}

Received: June 19, 2020 Revised: July 05, 2020 Accepted: September 04, 2020

\begin{abstract}
This study aimed to analyze the influence of the industrial growth and the effect on government tax potential of the South Sulawesi Province. The growth of the tax object affects government tax potential of South Sulawesi Province. Environmental resources affect government tax potential of the province. The study used multiple linear regressions on primary data. The population consisted of all officers and staff involved in regional work units. Revenue Service area in South Sulawesi Province counts 630 employees. The sampling method is purposive sampling random carried out based on specific objectives. The respondent qualifications are taken from the Technical Implementation Unit Office and the Department of Revenue. The number of respondents is 96 from the Head of UPTD and three of them are related with tax Section Chief Officer. The results showed that industrial growth has a significant and positive effect on the potential increase in tax of South Sulawesi. Growth in tax object significantly affects the potential increasing tax of South Sulawesi. Environmental resources significantly affect the potential Increase in tax. Practical recommendations for local government is to enhance tax potential, reduce bureaucracy in industrial licensing, and facilitate local farmers to get involved in economic contributions.
\end{abstract}

Keywords: Industrial Growth, Tax Object, Environmental Resource Potential Tax

JEL Classification Code: H23, H24, H71, F38

\section{Introduction}

Local tax levies became the mainstay of the acquisition of development funds in the era of regional autonomy. Implementation of regional autonomy effectively started in 2001 based on Law Number 22 of 1999 regarding regional government, which was substituted by Law Number 32 of 2004. Autonomy area according to Law Number 32 of 2004 on Regional Government Article 1 paragraph 5 of Regional Autonomy is the right, the authority and the obligation to set up and manage their affairs and interests of local communities by the legislation. So, the essence of autonomy is independence, the freedom to take initiative and

${ }^{1}$ First Author and Corresponding Author. Associate Professor, Department of Accounting, Universitas Muhammadiyah Makassar, Indonesia [Postal Address: Jl. Sultan Alauddin No.259, Gn. Sari, Kec. Rappocini, Kota Makassar, Sulawesi Selatan 9022, Indonesia] Email: rum.unismuh@gmail.com

${ }^{2}$ Associate Professor, Economics Department, Universitas Mulawarman, Indonesia. Email: anisakusumawardani@feb.unmul.ac.id

(c) Copyright: The Author(s)

This is an Open Access article distributed under the terms of the Creative Commons Attribution Non-Commercial License (https://creativecommons.org/licenses/by-nc/4.0/) which permits unrestricted non-commercial use, distribution, and reproduction in any medium, provided the original work is properly cited. be responsible themselves in organizing and arranging the building.

Regional autonomy is directed to accelerate the realization of community welfare through the improvement of services, empowerment and community participation. Besides, through broad autonomy, the regions are expected to improve their competitiveness by taking into account the principles of democracy, equity, justice, privilege and specificity, and potential and regional diversity. To improve the efficiency and effectiveness of the implementation of regional autonomy, this autonomy is focused on the districts/ municipalities because the districts/cities directly relate to the community. The role of local government in exploring and developing regional potentials as a source of local revenue will greatly determine the successful implementation of government tasks, development and community service in the region (Purnomo, 2009). Local governments are also expected to perform positively by establishing targeted policies to prevent further weakening of the South Sulawesi economy and to encourage a more balanced economic growth structure of districts in South Sulawesi through budgeting. The ability of local governments in managing their finances is outlined in the Regional Budget, which describes the ability of local government to finance the implementation of development tasks and the form of accountability in the 
implementation of regional autonomy. Law no. 32 of 2004 on the National Development Program, confirms that the program management of regional financial management in a professional, efficient, transparent, and responsible. The target to be achieved is an increasingly significant proportion of local revenues in financing for community service and development activities.

The study is also based on Government Regulation No.58 of 2005 on regional finance that includes the right of regions to collect local taxes and levies and lend regional obligations to hold local government affairs and pay bills to third parties, local revenue, territory, self-administered local wealth or by other parties in the form of money, securities, accounts receivable, goods and other rights, which can be valued with money, including property separated from local companies, and property of other parties controlled by local governments and or public interest.

This study, based on research on the financial condition of the region (Hevesi, 2003) is the ability of local governments to meet their expenditure budgets by taking the source of local revenue, while continuously providing services to the community. Community groups in good local financial conditions are well served even though local tax revenues have declined somewhat, as long-term economic conditions will improve, a better economic environments will be created, and resource development will improve over the long term. Furthermore, local financial conditions are determined by environmental factors of government, institutional factors, financial factors, fiscal revenue budgets, and decisions and actions of government executives (Hevesi, 2003; Oates, 1968).

Table 1: Local revenue growth South Sulawesi Provincial Fiscal Year 2010-2014 (in millions of rupiah)

\begin{tabular}{|l|c|c|c|c|c|}
\hline Year & PAD & $\begin{array}{c}\text { Fund } \\
\text { Balance }\end{array}$ & $\begin{array}{c}\text { Other Legal } \\
\text { Income }\end{array}$ & $\begin{array}{c}\text { Total APBD } \\
\text { Revenue }\end{array}$ & $\begin{array}{c}\% \\
\text { Per year }\end{array}$ \\
\hline 2010 & 1.545 .590 & 959.942 & 58,544 & $2,564,076$ & \\
\hline 2011 & 1.959 .516 & 1.106 .989 & 44.062 & $3,110,567$ & $21 \%$ \\
\hline 2012 & 2.198 .776 & 1.349 .193 & 885994 & $4,433,963$ & $43 \%$ \\
\hline 2013 & $2,560,046$ & 1.422 .166 & 885381 & 4.867 .593 & $10 \%$ \\
\hline 2014 & $3,029,122$ & 1531.386 & 942653 & 5503.161 & $13 \%$ \\
\hline
\end{tabular}

Source: Regional Revenue Service of Prov. South Sulawesi, 2015

Table 2: Contribution per type of revenue to total PAD of South Sulawesi Province Budget Year 2010 -2014 (in millions of rupiah)

\begin{tabular}{|l|c|c|c|c|c|c|}
\hline Year & Local tax & Levy Area & $\begin{array}{c}\text { Separate Regional } \\
\text { Wealth Management }\end{array}$ & $\begin{array}{c}\text { Other Legitimate } \\
\text { PAD }\end{array}$ & Total PAD & $\begin{array}{c}\% \\
\text { Per year }\end{array}$ \\
\hline 2010 & 1.334 .904 & 108.561 & 51.552 & 50673 & $1,545,590$ & \\
\hline 2011 & $1,729,076$ & 111.625 & 62367 & 56448 & 1.959 .516 & $27 \%$ \\
\hline 2012 & $1,949,194$ & 113.059 & 67557 & 68.966 & 2.198 .776 & $12 \%$ \\
\hline 2013 & $2,253,428$ & 60.529 & 71.057 & 175.042 & $2,560,046$ & $16 \%$ \\
\hline 2014 & $2,667,267$ & 94.596 & 74.599 & 192.661 & $3,029,122$ & $18 \%$ \\
\hline
\end{tabular}

Source: Regional Revenue Service Prov. Sul-Sel Year 2015.

Table 3: Revenue of Regional GDP and Contribution to PAD Nationally, Period of 2010, 2011 and 2012 (in million rupiahs)

\begin{tabular}{|l|l|c|c|c|}
\hline No. & \multicolumn{1}{|c|}{ Description } & $\mathbf{2 0 1 0}$ & $\mathbf{2 0 1 1}$ & $\mathbf{2 0 1 2}$ \\
\hline 1. & Local Taxes & $39,575,140$ & 50.199 .839 & 64.212 .601 \\
\hline 2 & Levy Area & 1.429 .812 & 1.235 .837 & 1.309 .072 \\
\hline 3. & Total PDRD & 41.004 .952 & 59.435 .676 & $65,521,672$ \\
\hline 4. & Total PAD & 47.331 .011 & 59.597 .218 & 75.070 .594 \\
\hline 5. & Local tax ratio to PAD & $83.61 \%$ & $84.23 \%$ & $85.54 \%$ \\
\hline 6. & Regional retribution ratio to PAD & $3.02 \%$ & $2.07 \%$ & $1.74 \%$ \\
\hline 7. & PDRD Ratio Against National PAD & $86.63 \%$ & $86.31 \%$ & $87.28 \%$ \\
\hline
\end{tabular}


This study is also based on the theory of Public Finance according to Islam (2009) stating that, to achieve the performance of financial management, the effective step taken is to control the efficiency of the use of funds and allocate resources to productive sources. The theory of public finance by Oates (1968) states that all units of government are always assumed to be independent in the management of taxes, income, and expenditure. Table 1 shows the regional income growth of South Sulawesi Province budget years from 2010 to 2014. The amount of PAD can contribute an average of $55.8 \%$ per year, even reaching $63 \%$ in 2011. Funds balanced/revenue transfers averaged 39, 4\% per annum and others legal clearance of $24 \%$ per year. Throughout the years from 2010 to 2014, South Sulawesi Province's regional income showed very significant growth, from Rp2.518 trillion in 2010 to Rp5,503 trillion in 2014. This means that, within five years, the regional income of South Sulawesi Province increased by Rp2.984 trillion, or $118.81 \%$. From 2010 through to 2014, the revenue of PAD increased by Rp1.529 trillion, or $10.19 \%$, from Rp1.545 trillion in 2010 to Rp3.029 trillion in 2014 , with an average increase of $20 \%$ per annum. The largest increase was contributed by regional tax revenue, which grew by Rp1.332 trillion, or $99.8 \%$, from Rp1.334 trillion in 2010 to Rp2.667 trillion in 2014.

Local tax revenues increased by $99.9 \%$, local tax contribution to PAD of South Sulawesi Province budget in years from 2010 to 2014 . Table 1.2 shows that the dominance of local tax revenue equals to $88.9 \%$ acceptance of local retribution of $4.7 \%$ revenue from the results of management of local wealth separated by $3.0 \%$ and receipts from other legitimate PAD by $3.3 \%$.

Table 1.3 shows that contribution of taxes and levies (PDRD) to PAD nationally in the year 2010 amounted to $86.63 \%$, the year 2011 amounted to $86.31 \%$, and the year
2012 amounted to $87.28 \%$. The achievement of PDRD contribution to the PAD for South Sulawesi Province in 2010 amounted to $96.1 \%$, in 2011 it was $93.9 \%$, and in 2012 it was 93.8\%. Based on data above the ratio of PDRD to PAD of South Sulawesi Province is above the national ratio.

Direct tax contribution to regional tax of South Sulawesi from 2010 to 2014 shows a decline. Direct tax revenues are the authority of provincial governments and are a significant source of revenue for routine financing and development in an autonomous region for the increase of the original regional revenue (PAD). Direct taxes in the form of motor vehicle taxes (motor vehicle taxes), motor vehicle refund (BBNKB), motor vehicle refund tax (PBBNKB), and surface water tax (PAP) are largely determined by the potential tax rate. The amount of revenue component of local taxes and levies is strongly influenced by the many rules and authorities that trigger an increase in tax objects. The authority should be adjusted with the relevant regulations (Riduansyah, 2003). Thus, there should be efforts to increase the potential tax to trigger direct tax revenue.

Table 4 shows a very significant decrease in the realization of direct taxes given the direct tax target area of South Sulawesi from 2010 to 2014. The question is whether the target tax is too high or the attainment of tax levies is declining. A review of the growth of the tax target from 2010 to 2014 also shows a very significant decline; it means that the tax target set is not high, but the tax potential underlying the determination of tax targets is greatly decreased. In other words, there are indications or phenomena that cause the taxes to be greatly reduced. Even if the growth of the tax target between 2012 and 2013 shows a decrease from 22.11 percent to 11.37 percent, while the realization of tax revenue increased from 12.6 percent to 14.07 percent, it means that tax revenue efforts are improving even though the taxes are declining.

Table 4: Realization and Direct Tax Contribution to Regional Taxes South Sulawesi Year 2010, until 2014

\begin{tabular}{|c|c|c|c|c|c|c|c|}
\hline \multirow{2}{*}{ Year } & \multicolumn{3}{|c|}{ PKB, BBNKB , PBBKB, PAP } & \multicolumn{2}{c|}{ Target Growth } & \multicolumn{2}{c|}{ Realization Growth } \\
\cline { 2 - 7 } & Target & Realsasi & $\%$ & Rp & $\%$ & Rp \\
\hline 2010 & 998.896 .105 .924 & $1,077,541,424,843$ & $107.87 \%$ & & & \\
\hline 2011 & 1.422 .840 .168 .818 & 1.438 .154 .112 .807 & $101.08 \%$ & 423.944 .062 .894 & $42.44 \%$ & 360.612 .687 .964 & $33.47 \%$ \\
\hline 2012 & 1.737 .457 .525 .263 & 1.619 .378 .277 .155 & $93.20 \%$ & 314.617 .356 .445 & $22.11 \%$ & 181.224 .164 .349 & $12.60 \%$ \\
\hline 2013 & 1.935 .048 .328 .213 & 1.847 .182 .870 .224 & $95.46 \%$ & 197.590 .802 .950 & $11.37 \%$ & 227.804 .593 .069 & $14.07 \%$ \\
\hline 2014 & 2.062 .022 .071 .500 & $1,935,604,507,752$ & $93.87 \%$ & 126.973 .743 .287 & $6.56 \%$ & $88,421,637,528$ & $4.79 \%$ \\
\hline
\end{tabular}

Source: Regional Revenue Service of Prov. South Sulawesi, 2015 
The efforts of the local government of South Sulawesi to attract direct taxes are very high. This is done with the provision of local tax incentives of $20 \%$ (excluding for twowheeled vehicles, tricycles, and motor vehicles red plate/ service). Vehicles are entitled to an incentive discount of $20 \%$ applicable from the invoice date of the vehicle purchase from 17 August to 31 December 2015. With such incentives, people can simply calculate the value of BBNKB to be paid, which is equivalent to $10 \%$ of the Value Selling Motor Vehicles, or the same BBNKB rates applicable in Jakarta and surrounding areas. In fact, for the long term, buying motor vehicles in South Sulawesi will be more profitable, because the PKB to be paid is only worth $1.5 \%$ of the Basic Tax Imposition (DPP), while in Jakarta it is $2 \%$. Another purpose of the decline in the BBNKB tariff is to minimize the distribution of motorized license plates with the identity from outside the region of South Sulawesi. It has proven to be very detrimental to the regional income of the tax sector, in particular the revenues of Transfer of Motor Vehicle Title and Motor Vehicle Tax in South Sulawesi Province.

The concession issued by the Provincial Government of Sulawesi implies the following:

a. Dealers shall immediately reduce the price/selling value of motor vehicles, at least by tax incentives, which is $20 \%$ of BBNKB. The value that should be paid by the buyer of the motor vehicle;

b. The calculation of the decline in the price/value of the sale of the vehicle shall be made before calculating the incentives/deductions/prizes /bonuses/discounts/ promos or such type provided by each motor vehicle dealer;

c. Dealers submit a new motor vehicle price list (after tax incentives) to the Head of South Sulawesi Provincial Revenue Office.

The great hope of Sulawesi Provincial Government is to be able to push the economy and development of area better. For that the people of South Sulawesi should do the transaction in the purchase of vehicles in South Sulawesi to pay taxes that can be used for the development of cities and districts throughout South Sulawesi. Starting from the description of the background, the formulation of the problem is whether the industrial growth, the growth of tax objects, and environmental resources affect the tax potential of South Sulawesi Provincial Government?

\section{Theoretical Background}

\subsection{Agency Theory}

According to the Agency theory, Mizruchi (2004) says agency conflict occurs because of the separation of functions between manager and owner, the weakness of investor function, and the effort to improve company performance. The agency theory formulated by Jensen and Meckling
(1979) describes the contractual relationship between principal and agent. Agency relationships as a contract under which one or more persons (the principals) engage another person (the agent) to perform some service on their behalf, which involves delegating some decision-making authority to the agent. The explanation above illustrates the agency relationship where there is a contract under which one party (principal/owner) employs another party (agent) to manage the company on behalf of the owner. Local government should work toward eliminating corruption and stabilizing macroeconomics in order to enhance local financial integration and local economic development growth (Bong $\&$ Premaratne, 2019). Furthermore, this theory raises the separation of ownership and control, which will lead to the social responsibility of agents. Social responsibility agent is to secure the welfare of various parties, both within organizations such as owners, managers, and employees, or outside the organization, that is the wider community.

\subsection{Public Sector Performance}

This research uses the public-sector performance theory. Under this theory, according to Shrestha (2015), there is a connection between basic organizational characteristics, general characteristics (demographics), and special characteristics that include knowledge, skill, ability, and others and the attainment of its objectives. The same is also put forward by Smith (2013). Another view about the performance of the public sector is proposed by Roberts (2003), the result of organizational efforts is achieved through the ability and deeds in certain situations. The involvement of government in sustainable management practice is transferred along the companies' supply chain through education and training of local companies (Lee $\&$ Tan, 2019). Therefore, performance is the result of the linkage between effort, ability, and task perception.

Performance measurement is the process of recording and measuring the achievement of the implementation of activities in the direction of achieving the goals through the results shown in the form of products, services or processes. In most organizations, this performance measure is the level of profit. However, public-sector organizations according to Dwiyanto (2001) cannot only use profit measures to assess organizational success because it is the primary goal of public-sector organizations not to generate profit, but to improve the welfare of society.

Performance measurement is a management tool to improve the quality of decision-making and accountability. By doing performance measurement, according to Osborne and Plastrik (2001), we can ascertain whether the decisionmaking is done precisely and objectively. Besides we can also monitor and evaluate the performance and compare it with the workplan and take action to improve the performance of 
the next period. The occurrence of increasing or decreasing productivity can be shown from this activity. Lane (2003) reveals that performance measurement is a process of assessing work progress against pre-determined goals and objectives. The information included in performance measurement includes (1) efficient use of resources in producing goods and services; (2) the quality of goods and services (how well goods and services are delivered to customers and how satisfied customers are); (3) results of activities compared with the intended purpose; and (4) the effectiveness of action in achieving the objectives.

Government agencies are pure non-profit oriented organizations. The performance of government agencies should be measured from both financial and non-financial aspects. Various aspects that must be measured include: (1) those inputs; (2) a group process; (3) group output; (4) group results; (5) categories of benefits; and (6) group effects. Besides, the scope of performance measurement is very wide. Performance measurement should include policies, planning and budgeting, quality, effectiveness, fairness (equity), and responsibility and accountability. The objectives of public-sector organizations are similar to the objectives of government agencies in general, which is satisfactory for external stakeholders who provide resources for the organization. But like most non-profit organizations, the identification of external stakeholders is more complicated than business organizations. Customers for non-profit organizations also have more complex demands and evergrowing expectations.

\subsection{Public Service}

Public services according to Osborne (2007) in the concept of the Reinventing Government paradigm, that government should be catalyzed, empowering society, encouraging the spirit of competition, oriented towards service mission, giving importance to outcome and not how to serve, prioritizing the interests of customers, entrepreneurial spirit, always trying to prevent problems or to behave in an anticipatory, decentralized and market-oriented manner. The paradigm of New Public Management (NPM) by Osborne (2007) suggests seven components in public service: the use of professional management, the use of work indicators, the use of greater control outputs, the shift of attention to the smallest units, the shift of higher competition, increased private sector closer to government, and budget savings and resource use.

Denhardt and Denhardt (2007) note that public service is to serve citizens rather than as customers, prioritizing the public interest, respecting citizenship more than entrepreneurship, strategic thinking, democratic acts, accountability in public services, which is not an easy one as it requires control and encourages people to improve productivity. Demir (2009) states that stewardship in the public-finance sector is the recording, management, and the arrangement of resources in the form of taxpayers and other resources.

\subsection{Resource Theory}

Theory of resources according to Wernerfelt (1984) states that the higher the resources used, the higher the amount of revenue collected. Olalla (1999) says that the existence of resources is the advantage of an organization when compared with other organizations. Further, Olalla said that the resources in the form of knowledge, skills, technology, and talent are a requirement that is crucial in a development organization.

Wahyudi's (2005) view of resources in public-finance management is the adequacy and availability of resources that support the implementation of strategies. The existence of the resources in question is environmental energy. Other resources that can be formed are the skills of individuals and community groups that undertake and create economic value in the form of market and processing resources generated from the environment.

\subsection{Human Capital}

Human resources according to Fernández, Montes, and Vázquez (2000) is an intangible resource that consists of knowledge or information. The people involved in local industry, and running the small- and mediumsized enterprises are regarded as human capital, which is becoming a major factor in the formation and development of an innovative economy and knowledge economy. Human capital development in local industries is taking into account the current global trends in the formation of an innovative economy and digitalization (Chulanova, Satybaldin, \& Koshanov, 2019). They are grouped into two categories, namely, dependent and independent human resources. Dependent human resources are into the overall system, while independent consist of three categories: the organizational capital, technological capital and relational capital. Furthermore, Fernández et al. (2000) say that human resources in an organization can take the form of human capital, which consists of the mastery of general knowledge and mastery of specialized technical knowledge; human resources is organizational capital that is included within the norms and governance of the organization.

Human resources, according to Mulgan (2005), are a set in the various intangible forms that every human being possesses, such as life experiences, knowledge, findings, energy, and enthusiasm to facilitate knowledge transfer. The main principle of human resource investment objectives is to minimize risks and maximize returns related to human 
interest in a community, so to do with human capital, it is difficult to understand whether these assets can be measured and quantified the value of human resource assets as assets tangible or not. Too many variables are involved to make more practical human capital. Furthermore, indicator of human capital is education, skill, and workability (Bruno, Miedzinski, Reid, \& Yaniz, 2008).

\subsection{Capital of Physical Resources}

Physical resources or physic capital accumulation are determined by government investment (Shioji \& Vu, 2012). Increased physical resources then contribute to improving the financial condition of a local government (Baldi, 2013). In addition, Mulganm (2005) defines physical resources as a provision of means and public space that can provide value and is viewed as capital. The main character is called capital because it can provide value to its users; on the other hand, the government can also give authority to its users, whether it can be used as agricultural land, plantation, entertainment, or industrial area. Furthermore, Mulgan (2005) emphasized that the availability of physical resources can contribute to an increase in the economy of a region.

Physical resources are the natural resources and man-made resources that are used to support the interaction between humans and their environment to achieve its goals (Barbier, 2010). We no longer consider the economic processes of the production of goods and services and produce prosperity, but depend on the accumulation of physical capital and human capital. Increasingly, a number of economies now receive the third form of "economic capital" in physical and nonphysical form for the functioning of the system of production economy, consumption, and overall welfare (Barbier, 2010). The concept of this physical capital is comprised of natural and environmental capital resources, availability and resources for the economy, often referred to as natural capital, and other technological innovations (Bruno et al., 2008).

\subsection{Public Finance Theory}

The Theory of Public Finance, according to Islam (2009), posits that the effective performance of financial management is determined by the efficient control of the use of funds and the allocation of resources to a more productive source. To achieve these objectives, the national development budget, either sourced from domestic revenues or sourced from loan funds, should be carefully allocated, so that the financed source can provide more tax resources, because to avoid economic distortions, until there is a deficit spending in the financial management of local government.

The theory of public finance by Oates (1968) states that all units of government are always assumed to be independent in the management of taxes, income, and expenditure. Oates further said that the financial policy is only issued to streamline the use of finance, in addition to stabilize services to the public with financial constraints set by the budget. Furthermore, Oates also said that fermentation against exports is determined by the financial condition and budget allocation of potential resources.

\section{Research Methods and Materials}

This study focused on SKPD South Sulawesi provincial revenue agency. The data collection was conducted during May 2016. The population in this study is all officials and related staff in the Regional Device Work Unit (SKPD) of the Regional Revenue Service within the local government of South Sulawesi Province. The method of selecting a sample is Purposive random sampling based on a specified purpose. The respondents are taken from the official of Department of Technical Application Unit (UPTD) of Regional Revenue Service. There is a total of 96 respondents from the Head of UPTD and three related Tax Section Heads. The type and source of data used in this study are primary data obtained from the respondents through questionnaires. Data were obtained on industrial growth, tax potential, and regions financial condition. Secondary data were from the local government of Regency/City and Province in South Sulawesi. The data obtained include financial data, revenue structure, and the amount of SKPD. Other secondary data are collected from the literature review, various books, journals, and the Internet.

\section{Results and Discussion}

Based on the results of data analysis shown in Table5, 55.3\% of local tax potential (Y) is influenced by industrial growth, growth of tax objects and environmental resources, and this means that $44.7 \%$ of potential local taxes are influenced by other variables outside the research variables used. This test aims to see whether the independent variables together influence the dependent variable. Table 5.15 below presents the results of statistical tests F.

Table 5: Anova

\begin{tabular}{|l|c|c|c|c|c|}
\hline & R & df & Mean Square & F & Sig. \\
\hline Regression & Square & 3 & 8.218 & 40.211 & $.000^{\text {a }}$ \\
\hline Residual & .567 & 92 & .204 & & \\
\hline Total & & 95 & & & \\
\hline
\end{tabular}


From the statistical test $\mathrm{F}$ in Table 5 , the value of $\mathrm{F}$ arithmetic amounted to 40,211 with a probability of 0.000 . Since probability value is less than 0.05 , then industrial growth variable, growth of tax object and environmental resource, together have a significant effect on local tax potency. The partial test is done to determine the effect of independent variables on the dependent variable by looking at the value of $t$ in the table coefficient calculated with the help of SPSS program. The significance level used is $5 \%$ or 0.05 . The test criteria used are as follows: if p-value $<0.05$, then $\mathrm{H} 0$ is rejected and, if p-value $>0$, then Ho is accepted. This test is also used to know how big is the influence of industrial growth, growth of tax object and environmental resource by looking at $t$ value of each variable. Table 5.16 presents the results of statistical tests $t$.

Based on the analysis of results, the influence of industrial growth, the growth of tax objects and environmental resources to the potential of local taxes on the Regional Revenue of South Sulawesi can be interpreted as follows.

Industrial growth has a positive and significant impact on the potential of local taxes on the local revenue of South Sulawesi. This means that industry growth accounts for the largest contribution to the smallest total local tax revenues and total local revenue in South Sulawesi. The people involved in local industry are regarding as human capital and become a major factor in the formation and development of an innovative economy and knowledge economy (Chulanova et al., 2019). The results of this study support research conducted by Haniz and Sasana (2014), which examines the analysis of factors that affect tax revenue in the Tegal City area. The results of his analysis indicate that per capita income, taxpayers, and economic growth in Tegal City since 1991 until 2010 have a significant effect on tax revenue for Tegal City.

Aji (2013), however, suggests that since the introduction of regional autonomy in 2001, all the authority is in the central government, especially on regional finance. Fiscal decentralization is one of the powers given by the central government to local governments. Aji (2013) analyzed the factors affecting tax revenues of Wonogiri regency in the era of fiscal decentralization. This study aims to analyze the factors that affect the tax revenue of Wonogiri regency in the era of fiscal decentralization from 2006 to 2011. This study uses local tax revenue data and the number of industries (small, medium, and large). The results of an analysis done by using multiple regression analysis reached the conclusion that the number of industries does not affect the tax revenue of Wonogiri regency.

Different also with the result of research of Fatah (2015) explain about $\mathrm{p}$ urban development is rapidly evolving along with the proliferation of educational spaces, shopping centers, industrial enterprises and local businesses that thrive in various corners of the City, which ultimately require billboards as a means of promoting public recognition. This situation encourages the City Government to explore the potential of large Local Taxes in the field of billboards to increase the Regional Tax Revenue. Knowing the effect of population and the amount of industry on advertisement tax revenue and its effect on local tax revenue is the purpose of this research. The result of path analysis in research shows that the number of industries negatively affects Regional Tax Revenue.

The growth of tax objects has a positive and significant effect on the potential of local taxes in increasing the regional income of South Sulawesi, meaning that each unit of increase in tax object growth affects the increase of local tax potency. Khotimah (2014) suggested that to support the implementation of regional autonomy maximally, the government issued a policy in the field of regional acceptance with the orientation to increase the ability of a region to explore its potentials. In his research Khotimah (2014) explains that one potential city area, Mojokerto tax hotel, experienced an annual increase in the period from 2009 to 2013. The method used in this research is descriptive quantitative. The aim of this research is to assess the potential of hotel tax by taking a sample of seven hotels, out of nine hotels. The results show the potential of the hotel tax from the years 2009 to 2013 experienced growth annually, but the tax effectiveness in Mojokerto from the years 2009 to 2013 was not good - the hotel tax realization is smaller than the potential of the hotel tax. In addition, there is a very little information on the realization of contributions to local taxes from 2009 to 2013.

Table 6: Coefficients

\begin{tabular}{|l|c|c|c|c|c|}
\hline & $\begin{array}{c}\text { Unstandardized } \\
\text { Coefficients } \\
\text { B }\end{array}$ & Std. Error & $\begin{array}{c}\text { Standardized } \\
\text { Coefficients } \\
\text { Beta }\end{array}$ & Sig. \\
\hline (Constant) & .004 & .409 & & .011 & .992 \\
\hline Industrial Growth & .545 & .058 & .644 & 9.378 & .000 \\
\hline Growth & .187 & .052 & .255 & 3,566 & .001 \\
\hline Tax Objects & & & & \\
\hline Environmental resources & .251 & .077 & .235 & 3.284 & .001 \\
\hline
\end{tabular}


This contrasts with the results of the study by Ardhiansyah, Rahayu, and Husaini (2014) on the analysis of the potential of hotel taxes and restaurant taxes and their contribution to the income of the Region (PAD) (Case Study On Revenue Service of Batu City Year 2011-2013). The result of the research by using the formula of potency shows that the potential of hotel taxes and restaurant taxes is very big, the potential extract from hotel tax is $32.48 \%$ or it can be said to be not effective from the realization of 2011, and for restaurant excavation tax is $77.22 \%$, less effective than the realization in 2011. The calculation of the rate of growth of hotel tax in 2012 amounted to $55.85 \%$ (quite successful), for restaurant tax rate growth rate of $33.78 \%$ (less successful) in 2012. Calculation of hotel tax contribution to PAD by $11.19 \%$ (less) in 2011, while for restaurant taxes against PAD of $6.54 \%$ (very less) in 2011.

In line with Alam (2014), research results showed that the average rate of growth of hotel and restaurant tax for ten years $(1995,1996-2005)$ amounted to $19,46 \%$ per year. The calculation of hotel and restaurant tax potential for the fiscal year 2006 is big enough to reach Rp1,453,849,480, but the new one can realize Rp229.424.000, just about $36.70 \%$. The factors that most influence the acceptance of hotel and restaurant tax is then the level of PDRB Palopo City, the number of tourist visits, and from the number of hotel rooms and lodging. The SWOT analysis shows that the general strategy that can be used to improve hotel and restaurant tax revenues is a concentrated growth strategy. To support this strategy can be done by improving both internal and external controls, removing products that are deemed incompatible with current conditions, and increasing the market share.

Environmental resources have a positive and significant impact on the potential for local taxes in increasing the local income of South Sulawesi. In line with the research by Mostopha (2010), we try to answer two questions: How is the natural resource-sharing given to the region? What efforts have been done in the framework of conservation of natural resources? In central and regional financial balancing schemes, natural resource-sharing funds include oil and gas, and non-oil and gas (mining, forestry, and fisheries). On the other hand, the Special Allocation Fund for the environment is still small. Yet, there are so many problems related to the environment (pollution and or damage). The natural resource-sharing and tax-sharing mechanisms aim to reduce the vertical imbalance between central and regional levels. However, the profit-sharing pattern may potentially sharpen horizontal imbalance experienced between the producing region and non-producing natural resources. Horizontal inequality is caused because in reality, the characteristics of regions in Indonesia are very diverse.

According to Astuti and Haryanto (2005), some areas are endowed with abundant natural resources such as in Riau, Aceh, East Kalimantan and Papua, in the form of petroleum and natural gas (oil, gas, mining, and forestry). Some areas actually do not have great natural wealth, but because their economic structure has been well organized, the potential tax can be optimized so that the area becomes rich.

\section{Recommendations}

There is a need for strong commitment between taxpayers, tax managers and local government of South Sulawesi for the implementation and compensation of the Local Tax Regulation, so that there is obligation of society and local government to support each other to increase local taxes. There needs to be an effort to increase local taxes to increase local revenue. Therefore, the Government of South Sulawesi should be intensively attentive to the development of local tax revenues by way of exploring the potential for local taxes and conducting fundamental research on the causes of the weakening of the potential for local taxes. It is necessary to cooperate between independent institutions as partners to observe and calculate the potential for taxes accruals for the government to maintain its development on an ongoing basis through local tax revenue. Moreover, the involvement of government is transferred along the companies' supply chain through education and training of local companies (Lee \& Tan, 2019). The Provincial Government of South Sulawesi should consider reviewing the policies on local tax levies.

For local taxes, there should be re-registration and sanctions to local taxpayers who do not pay their taxes on time. Further research should be done by using other variables as factors that influence the potential increase in local taxes as a source of revenue for the Regional Revenue Service South Sulawesi Province. Practical recommendations for local government include enhancing tax potential, reduce bureaucracy in industrial licensing and facilitate local farmers to get involved in economic contributions by intensifying investment, fertilizing, and caring before harvesting. And the local government must protect standard price in local market, and in return, local farmers can get more valuable income.

\section{Conclusions}

In conclusion, the results of the study indicate that industrial growth has a significant and positive effect on the potential for tax increase in South Sulawesi. This is caused by the developing industry that will absorb labor and raw materials from the surrounding environment, so that it will automatically increase the people's income. The growth of the tax object is significantly influenced by the potential for tax increases in South Sulawesi. This is because the tax object is the basis for calculating the payable tax, and this tax object is a complement to tax sources, in this case the industry and labors itself. The environmental resources 
have a significant effect on the potential for increased taxation, because environmental resources are the product of production from farmers and gardeners and sea products that form the basis for tax objects, income of farmers and cultivators and fishermen, as well as industrial input as end users. This study identifies the dependency on employees as a source of innovation.

\section{References}

Aji, A. D. (2013). Analysis of Factors Affecting Regional Tax Receipts in Wonogiri Regency In Fiscal Decentralization Era. Surakarta, Indonesia: Muhammadiyah Surakarta University. [Indonesian]

Alam. (2014). Potential Revenue Receipts the Original Region of Hotel and Restaurant Taxes in Palopo City. Makassar, Indonesia: Hasanuddin University. [Indonesian]

Ardhiansyah, D., Rahayu, S. M., \& Husaini. (2014). Potential Analysis of Hotel Danpajak Restaurant Tax and its Contribution to the Regional Original Income (Case Study on Revenue Service of Batu City Regional Year 2011-2013). 14(1). [Indonesian]

Astuti, E. S., \& Haryanto, J. T. (2005). Analysis of General Allocation Funds (DAU) in the Era of Regional Autonomy Case Study 30 Provinces. Journal of Management of Indonesian Entrepreneurs, 12(4), 38-48. [Indonesian]

Baldi, G. (2013). Physical and human capital accumulation and the evolution of income and inequality. Journal of Economic Development, 38(3), 57-83. Available at: http://www.jed.or.kr/ full-text/38-3/3.pdf

Barbier, E. B. (2010). Poverty, development, and environment. Environment and Development Economics, 15(6), 635-660. https://doi.org/10.1017/S1355770X1000032X

Bong, A., \& Premaratne, G. (2019). The Impact of Financial Integration on Economic Growth in Southeast Asia. Journal of Asian Finance, Economics and Business, 6(1), 107-119. http:// doi.org/10.13106/jafeb.2019.vol6.no1.107

Bruno, N., Miedzinski, M., Reid, A., \& Yaniz, M. R. (2008). Sociocultural determinants of innovation. Amsterdam, Netherlands: Technopolis Group.

Chulanova, Z. K., Satybaldin, A. A., \& Koshanov, A. K. (2019). Methodology for assessing the state of human capital in the context of innovative development of the economy: A threelevel approach. Journal of Asian Finance, Economics and Business, 6(1), 321-328. http://doi.org/10.13106/jafeb.2019. vol6.no1.321

Demir, T. (2009). Politics and administration: Three schools, three approaches, and three suggestions. Administrative Theory \& Praxis, 31(4), 503-532.

Denhardt, J. V., \& Denhardt, R. B. (2007). The new public service: Serving, not steering. New York, NY: ME Sharpe.

Dwiyanto, A. (2001). Public Service Performance in the CPPS. Gadjah Mada University Policy Brief, Number 01. Yogyakarta, Indonesia: Gadjah Mada University. [Indonesian]
Fatah, A. A. (2015). The Influence of Population and Number of Industries on Receipt of Advertisement Tax and Its Effect on Local Tax Revenue (Study on Local Revenue Service of Malang City Period Year 2000-2013). Journal of Brawijaya University, 5(1). [Indonesian]

Fernández, E., Montes, J. M., \& Vázquez, C. J. (2000). Typology and strategic analysis of intangible resources: A resource-based approach. Technovation, 20(2), 81-92.

Haniz, N. F., \& Sasana, H. (2014). Analysis of Factors That Influence Tegal City Regional Tax Revenue. Diponegoro Journal of Economics, 3(1), 1-13. [Indonesian]

Hevesi, A. G. (2003). Local government management guide: financial condition analysis. New York, NY: Office of the State Comptroller. Division of Local Government Services and Economic Development.

Islam, S. M. A. (2009). Government expenditure and theory of efficient private and public finance. Journal of the Bangladesh Agricultural University, 7(2), 367-371.

Jensen, M. C., \& Meckling, W. H. (1979). Theory of the firm: Managerial behavior, agency costs, and ownership structure. In: Economics social institutions (pp. 163-231). New York, NY: Springer.

Khotimah, Q. (2014). Analysis of Potential and Effectiveness of Hotel Tax Receipts in Increasing Local Original Income (Case Study of Revenue and Financial Asset Management of Mojokerto City)., Malang, Indonesia: Universitas Brawijaya. [Indonesian]

Lane, J.-E. (2003). Management and public organization: The principal-agent framework. Working Paper. University of Geneva and National University of Singapore.

Lee, J. W., \& Tan, W. N. (2019). Global Corporate Citizenship: Cross-cultural Comparison of Best Practices in the Global Automotive Industry. Journal of Asian Finance, Economics and Business, 6(1), 261-271. https://doi.org/10.13106/jafeb.2019. vol6.no1.261

Mizruchi, M. S. (2004). Berle and Means revisited: The governance and power of large US corporations. Theory and Society, 33(5), 579-617.

Mostopha. (2010). Funds for Revenues and Conservation of Natural Resources in Indonesia Decentralization Period. Journal of Economics \& Education, 8(2). [Indonesian]

Mulgan, G. (2005). Physical capital: How great places boost public value. London, UK: CABE.

Oates, W. E. (1968). The theory of public finance in a federal system. The Canadian Journal of Economics/Revue Canadienne d'Economique, 1(1), 37-54.

Olalla, M. F. (1999). The resource-based theory and human resources. International Advances in Economic Research, 5(1), 84-92.

Osborne, D. (2007). Reinventing government: What a difference a strategy makes. 7th Global Forum on Reinventing Government: Building Trust in Government. 26-29 June 2007, Vienna, Austria. 
Osborne, D., \& Plastrik, P. (2001). Trimming Bureaucracy: Five Strategies towards Entrepreneurial Government. Jakarta, Indonesia: CV. Taruna Grafica. [Indonesian]

Purnomo. (2009). Analysis of Independence and Performance of Regional Finance in Implementation of Regional Autonomy in Yogyakarta City Government, Semarang, and Surakarta Year 2001-2006. Surakarta, Indonesia: Muhammadiyah University of Surakarta. [Indonesian]

Roberts, G. E. (2003). Employee performance appraisal system participation: A technique that works. Public Personnel Management, 32(1), 89-98.
Shioji, E., \& Vu, T. K. (2012). Physical capital accumulation in Asia 12: Past trends and future projections. Japan and the World Economy, 24(2), 138-149.

Shrestha, S. (2015). Measuring customer satisfaction: a case study. Kuopio, Finland: Kuopio Setlementti Puijola RY.

Smith, R. D. (2013). Strategic planning for public relations. Abingdon, UK: Routledge.

Wahyudi, K. (2005). Public Bureaucracy Accountability: Sketches in the Transition Period. Jogjakarta, Indonesia: MAP-UGM Dan Pustaka Pelajar. [Indonesian]

Wernerfelt, B. (1984). A resource-based view of the firm. Strategic Management Journal, 5(2), 171-180. 